\title{
Immunological Aspects of Formulated Drugs against Typhoid
}

\author{
S. S. Haque ${ }^{1, *}$, W. A Siddique ${ }^{2}$, A. Sharan ${ }^{1}$, U. Kumar ${ }^{1}$, R. Sharma ${ }^{1}$ \\ ${ }^{1}$ Department of Clinical Biochemistry, Indira Gandhi Institute of Medical Sciences, Patna, 800014, Bihar, India \\ ${ }^{2}$ Department of Biochemistry, Hamdard University, New Delhi, 1100062, India
}

\begin{abstract}
Typhoid fever remains a major health problem in India and other developing countries. Antimicrobial resistance has sequentially emerged to number of drugs posing patient treatment challenges, that thus it has necessitated the search of formulated drugs for its treatments. Nitric oxide (NO) is a unique molecule produced in a biological system. Previous studies have suggested that exogenous administration of L-arginine results in increased NO production, indicating that endogenous substrate is insufficient for maximal NO production. Considering these facts, it was thought pertinent to see the effect of oral administration of NO precursor i.e. L-Arginine. Formulation of NO precursor and ciprofloxacin are used in different concentration, which shows better therapeutic results against experimentally induced Salmonellosis.
\end{abstract}

Keywords Typhoid, Bacterial Agglutination, Nitric oxide, Ciprofloxacin

\section{Introduction}

Enteric fever or Typhoid fever is a systemic infection caused by the human adapted pathogens Salmonella. Salmonella causes of febrile illness in crowded populations with inadequate sanitation that are exposed to unsafe water and food and also pose a risk to travelers visiting countries of endemicity[1]. Ciprofloxacin (DNA gyrase blocker) has successfully been used to treat typhoid fever in adults and children[2-4]. It has been documented that ciprofloxacin penetrates tissue well and it not only reduced the case fatality rate but also shortened the course of illness to a great extent. To obtain better understanding of the pathogenesis of typhoid fever, it seems crucial to elucidate the host defense function of Nitric oxide (NO) against Salmonella. Nitric oxide (NO) is an important messenger molecule with biological functions as a powerful vasodilator agent. Lipopolysaccharide (LPS) is one of the most powerful activators of the cytokine cascade, as well as of NO synthesis[5]. Since NO is produced by stimulated macrophages has been implicated in the inhibition or killing of various microorganisms by inhibiting the respiratory cycle and the synthesis of adenosine triphosphate and DNA[6,7]. Proinflammatory cytokines such as interferon-gamma, interleukin-1beta, and other cytokines are modulators of the inflammatory reactions and many of them facilitate induction of the inducible isoform of NO synthase (iNOS), thus they could mediate excessive production of $\mathrm{NO}[8]$. Nitric

* Corresponding author:

sshaq2002@yahoo.co.in (S. S. Haque)

Published online at http://journal.sapub.org/ajb

Copyright (C) 2011 Scientific \& Academic Publishing. All Rights Reserved oxide (NO) produced by host phagocytic cells plays a major role in innate immunity, in large part because of the ability of NO to inhibit or kill a broad range of microorganisms[9]. By targeting protein thiols and metal centers[10], NO can block essential microbial physiological processes, including respiration[11] and DNA replication[12].

\section{Material and Methods}

\subsection{Dose and Dosage}

\subsubsection{Animals}

Swiss albino mice (25-30g) 6-8 weeks old were obtained from the central animal house of Hamdard University, New Delhi, India. The animals were kept in Poly-propylene cages in an air-conditioned room at $22^{\circ} / 25^{\circ} \mathrm{C}$ and maintained on a standard laboratory feed (Amrut Laboratory, rat and mice feed, Navmaharashtra Chakan Oil Mills Ltd, Pune) and water ad libitum. Animals were allowed to acclimatize for one week before the experiments under controlled light/dark cycle $(14 / 10 \mathrm{~h})$. The studies were conducted according to ethical guidelines of the "Committee for the purpose of control and supervision of Experiments on Animals (CPCSEA)" on the use of animals for scientific research.

\subsubsection{Bacteria}

In this experiment only Salmonella typhimurium (wild) was used. The standard strain of this pathogen was obtained from the National Salmonella Phage Typing Centre, Lady Harding Medical College, New Delhi, India. This bacterial strain was further confirmed by the Department of Microbiology, Majeedia Hospital, New Delhi, India. The drug was 
administered orally and S. typhimurium intraperitoneally.

Animals were divided into six groups. Each group comprised of six animals. The study comprised of following treatment schedule. (Table -1)

Table 1.

\begin{tabular}{|c|c|}
\hline Groups & Treatments \\
\hline Group1 & Negative control (Normal Saline) \\
\hline Group2 & Positive control S.typhimurium $\left(0.6 \mathrm{xLD}_{50}\right)+$ Saline \\
\hline Group3 & $\begin{array}{l}\text { S.typhimurium }\left(0.6 \times \mathrm{XD}_{50}\right) \\
+ \text { +Ciprofloxacin }(400 \mathrm{mgper} \mathrm{kg} \mathrm{b.} \mathrm{wt)}\end{array}$ \\
\hline Group4 & $\begin{array}{l}\text { S.typhimurium }\left(0.6 \times \mathrm{xD}_{50}\right) \\
+ \text { Arginine }(1000 \mathrm{mg} \text { perKg b.wt })\end{array}$ \\
\hline Group5 & $\begin{array}{l}\text { S.typhimurium }\left(0.6 \mathrm{xLD}_{50}\right)+\text { Arginine }(500 \mathrm{mg} \text { per } \mathrm{kg} \mathrm{b} . \mathrm{wt}) \\
+ \text { Ciprofloxacin }(200 \mathrm{mg} \text { per kg b. wt) }\end{array}$ \\
\hline Group6 & $\begin{array}{l}\text { S.typhimurium }\left(0.6 \times \mathrm{LD}_{50}\right)+\operatorname{Arginine}(250 \mathrm{mgper} \mathrm{kg} \text { b. wt }) \\
+ \text { Ciprofloxacin }(200 \mathrm{mg} \text { per kg b. wt })\end{array}$ \\
\hline
\end{tabular}

Effects of above drugs on infected mice by S. typhimurium were analyzed. Post-treatment of drugs were done at above dose orally to the experimental animals, first group was considered as control that receive only saline, second group considered as positive control which was challenged with sub lethal dose of $S$. typhimurium $\left(0.6 \mathrm{xLD}_{50}\right)$ along with saline. Third group was challenged with sub lethal dose of $S$. typhimurium and given only full dose of ciprofloxacin. Fourth group was challenged with sub lethal dose of $S$. $t y$ phimurium and then mice were treated with full dose of Arginine only. In fifth and sixth group animals were challenged with $S$. typhimurium and then half and one fourth dose of Arginine was administered along with half dose of Ciprofloxacin respectively.

\subsubsection{Preparation of Sonicated Antigen}

The sonicated antigen was made as described by Tiwari and Kamat, (1986)[13]. Briefly, S. typhimurium was grown at $37^{\circ} \mathrm{C}$ as stationary overnight cultures on nutrient agar was suspended in phosphate buffered saline (PBS), pH 7.2. Bacteria were washed in PBS and disrupted by sonication (Ultrasonic Processor, Heat system Ultrasonic, Inc, USA). The resultant material was centrifuged at $10,000 \mathrm{rpm}$ for 1hour. The supernatant was lyophilized and the protein content of the lyophilized material was estimated.

\subsection{Statistical Analysis}

All data are expressed as means \pm standard errors of the means (SEM). The statistical difference was determined by the two-tailed unpaired $t$ test. A $P$ of $<0.05$ was considered statistically significant.

\section{Results}

\section{Bacterial agglutination assay}

Animals were sensitized with S. typhimurium and the effect of drugs was seen in bacterial agglutination. On day 8 mice were immunized with heat-killed bacteria to raise the antibodies. Interaction of bacteria (pre-coated in the plate) with anti-serum showed positive bacterial agglutination clumping at the mean dilution of 799 was observed where as in case of drugs treated mice it was found to be $840,420,850$ and 1376. Result has been summarized in Figure 1.

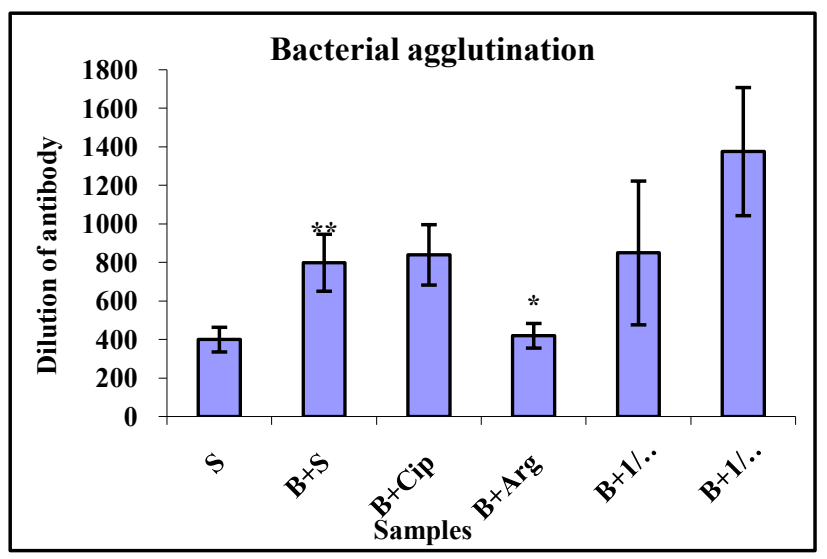

Figure 1. Bacterial agglutination tests: mice treated with arginine, ciprofloxacin and their combination. $\mathrm{S}=$ Saline, $\mathrm{B}+\mathrm{S}=S$. typhimurium + Saline, $\mathrm{B}+\mathrm{Cip}=$ S.typhimurium $+400 \mathrm{mg}$ per $\mathrm{kg}$ b. wt Ciprofloxacin, $\mathrm{B}+\mathrm{Arg}=S$. typhimurium $+1000 \mathrm{mg}$ per $\mathrm{kg}$ b. wt L-Arginine, $\mathrm{B}+1 / 2 \mathrm{Arg}+1 / 2 \mathrm{Cip}=S$. typhimurium $+500 \mathrm{mg}$ per $\mathrm{kg} \mathrm{b}$. wt Arginine $+200 \mathrm{mg}$ per $\mathrm{kg}$ b. wt ciprofloxacin, B+1/4Arg+1/2Cip=S.typhimurium $+250 \mathrm{mg}$ per $\mathrm{kg} \mathrm{b}$. wt Arginine $+200 \mathrm{mg}$ per kg b. wt Ciprofloxacin

Values are significantly different $* \mathrm{p}<0.05$ and ${ }^{* *} \mathrm{p}<0.01$

\section{Discussion}

\subsection{Immunological Assessment}

L-arginine is a versatile amino acid that plays a crucial role in the normal function of several organs systems including immune system. Dietary supplementation enhances cellular and humoral immune responses. Inducible nitric oxide synthase is positively modulated by IFN- $\gamma$ and TNF- $\alpha$ in murine typhoid[16,17]. These antibodies failed to suppress the early growth of Salmonella in the reticuloendothelial system[18-20] and the animals succumb within 7-8 days after challenge with wild type Salmonella.

\subsection{Bacterial Agglutination Assay}

The augmentation of humoral immune response against $S$. typhimurium by drugs is evidenced by increase in the level of antibody in mice. Result has been summarized in Figure 1.

The significant increase in humoral immune respose is due to immunostimulatory effect of L-arginine.

\section{Conclusions}

Animals were sensitized with S. typhimurium and the effect of drugs was seen in bacterial agglutination. Positive bacterial agglutination clumping at the mean dilution of 768 was observed whereas in case of drugs combination treated mice it was found to be $896,384,768$ and 1408 . 


\section{REFERENCES}

[1] Whitaker JA, Franco-Paredes C, del Rio C, Edupuganti S. Rethinking typhoid fever vaccines: implication for travelers and people living in highly endemic areas. J Travel Med 2009 ; 16:46-52

[2] Bhattacharya, S. K., M. K. Bhattacharya, P. Dutta, M. R. Saha, D. Dutta, R. Rasaily, A. Saha, and S. C. Pal. 1992. Multi resistant typhoid fever. Natl. Med. J. India 5:41(Letter)

[3] Mondal, B. K., P. Flegg, E. Durbar, K. Whole, and J. Brennand. 1987. Ciprofloxacin in enteric fever. Chemotherapia 6(Suppl.): 492-493

[4] Sen,S.,R.S. Goyal, and R. Dev. 1991. Ciprofloxacin in the management of multidrug resistant typhoid fever. Indian Pediatr. 28:417-419

[5] Such, J., J. Donald, Hillebrand, C. Guarner, L. Berk, P. Zapater, J. Westengard, C. Peralt G. Soriano, J. Pappas and B.A. Runyon, 2001. Tumor Necrosis Factor-á, Interleukin-6, and Nitric Oxide in Sterile Ascitic Fluid and Serum from Patients with Cirrhosis Who Subsequently Develop Ascitic Fluid Infection. Digestive Diseases and Sciences, 46(11): 2360-2366

[6] Lowenstein, C.J., J.L. Dinerman, S.H. Snyder, 1994. Nitric oxide: a physiologic messenger. Ann Intern Med; 120: 227-237

[7] Moncada, S., A. Higgs, 1993. The Larginine- nitric oxide pathway. N Engl J Med., 329:2002-2012

[8] Fang FC. Antimicrobial reactive oxygen and nitrogen species: Concepts and controversies Nat. Rev. mechanism. Cell.2001; 106:675-683

[9] Tiwari $H$ and Kamat PS. (1986). Cross-reactions in cell-mediated immunity to Salmonella enteric fever. J Med Microbiol. 21, 233-237

[10] Everest P, Roberts M and Dougan G. (1998). Susceptibility to Salmonella typhimurium infection and effectiveness of vaccination in mice deficient in the tumor necrosis factor alpha p55 receptor. Infect Immun. 66, 3355-3364

[11] Mastroeni P, Harrison JA and Robinson JH. (1998) Interleukin-12 is required for growth of attenuated aromat- ic-compounds-dependent Salmonellae in BALB/c mice, role of gamma interferon and macrophage activation. Infect Immun. $66,4767-4776$

[12] Hormache CE, Mastroeni P, Arena A, Uddin J and Joysey HS. (1990). T-cells do not mediate the initial suppression of a Salmonella infections in the RES. Immunology. 70, 247-250

[13] Hess J, Ladel C, Miko D and Kaufmann SHE. (1996). Salmonella typhimurium aroA-infection in gene-targetted immonudeficient mice. J Immunol. 156, 3321-3326

[14] Giovannoi G, Land JM, Keir G, Thompson EJ, Heales SJR. Adaptation of the nitrate reductase and Griess reaction method for the measurement of serum nitrate plus nitrite levels. Ann Clin Biochem 1997; 34 : 93-98

[15] Steven S Gross. Nitric oxide : Pathophysiological mechanisms. Annu Rev Physiol 1995;46

[16] Mastroeni P, Arena A, Costa GB, Liberto MC, Bonina L and Hormaeche CE. (1991) Serum TNF in mouse typhoid and enhancement of a Salmonella infection by anti-TNF antibodies. Microb Pathogen. 11, 33-38

[17] Mackaness GB, Blanden RV and Collins FM. (1966). Host parasite relations in mouse typhoid. J Exp Med. 124, 585-591

[18] Collins FM and Mackaness GB. (1968). Delayed hypersensitivity and Arthus reactivity in relation to host-resistance in Salmonella-infected mice. J Immunol. 101, 830-845

[19] Sztein, M. B., S. S. Wasserman, C. O. Tacket, R. Edelman, D. Hone, A. A. Lindberg, and M. M Levine. 1994. Cytokine production patterns and lymphoproliferative responses in volunteers orally immunized with attenuated vaccine strains of Salmonella typhi. J. Infect. Dis. 170:1508-1517

[20] Rowe B, Ward LR, Threlfall EJ. Multidrug-resistant Salmonella Typhi: a worldwide epidemic. Clin Infect Dis 1997; 24:S106-9.

[21] K.Umezawa, T., Akaike, S. Fujii, M. Suga, K. Setoguchi, A. Ozawa, A. and H.Maedia, 1997, Induction of nitric oxide synthesis and xanthine oxidase and their roles in the antimicrobial mechanism against Salmonella typhimurium infection in mice. Infect Immun. 65, 2932-2940 